\title{
The effects of some humic substances and vermicompost on phosphorus transformation rate and forms in a calcareous soil
}

\author{
M. Hejazi Mehrizi ${ }^{1 *}$, M. Sarcheshmehpour ${ }^{1}$, Z. Ebrahimi $^{1}$ \\ ${ }^{1}$ Department of Soil Science, Faculty of Agriculture, Shahid Bahonar University of Kerman, Kerman, Iran, \\ 7616914111.*Corresponding author :mhejazi@uk.ac.ir
}

\begin{abstract}
The role of some humic substances (HS) on phosphorus (P) bioavailability and fractions was investigated in a greenhouse study using a calcareous soil from Eastern, Iran. Soils were treated with two levels (2 and $4 \%$ ) of Humic Acid (HA), Fulvic acid (FA), Vermicompost (Verm) and their mixtures including FA+HA and FA+HA+Verm, and incubated for 24, 360, 720 and $1080 \mathrm{~h}$. The Olsen-P was determined in amended and nonamended soils after incubation time. The P release was modeled by Parabolic, Power and Elovich equations to determine the transformation rates. Since the maximum $\mathrm{P}$ release was found in vermicompost treated soil, $\mathrm{P}$ was sequentially extracted with $\mathrm{H}_{2} \mathrm{O}, \mathrm{NaHCO}_{3}, \mathrm{NaOH}$ and $\mathrm{HCl}$ at 24 and $1080 \mathrm{~h}$ after incubation. The highest released $\mathrm{P}$ was measured in vermicompost treatment and decreased as follows: $\mathrm{HA}+\mathrm{FA}+\mathrm{Verm}>\mathrm{HA}+\mathrm{FA}>\mathrm{HA}>\mathrm{FA}>\mathrm{CO}$. The decrease of $\mathrm{P}$ release data was best described by Parabolic equation $\left(\mathrm{r}^{2}=0.83-0.93, \mathrm{SE}=0.51-2.91\right)$. Higher transformation indices of vermicomopost amended soil than other treatments showed more efficiency of vermicompost to release of phosphorus in soil. $\mathrm{H}_{2} \mathrm{O}-\mathrm{P}, \mathrm{NaHCO}_{3}-\mathrm{P}$ and $\mathrm{NaOH}-\mathrm{P}$ increased after vermicompost application and converted to $\mathrm{HCl}-\mathrm{P}$ fraction so that at the end of the experiment, calcium phosphates comprised 69 and $43 \%$ of inorganic $\mathrm{P}(\mathrm{Pi})$ at 2 and $4 \%$ vermicomopost treatments, respectively. Results of the study showed that humic substances could increase $\mathrm{P}$ extractability and availability in soil.
\end{abstract}

Keywords: Phosphorus fractionation, kinetic models, P release

\section{Introduction}

Calcareous soils cover 600 million ha of arable lands in the world (Leytem and Mikkelson, 2005) which their management to increase crop production assumes a great deal of interest in the present time wherein the available land area for cultivation decreases with time. The plant availability of $\mathrm{P}$ in these soils is often below the required amount for optimum crop production due to precipitation of $\mathrm{P}$ with calcium ion or sorption of $\mathrm{P}$ by carbonate minerals (Bai et al., 2013). Chemical fertilizers have been continuously applied during the last years to raise soil available P (Bai et al., 2013). However, inappropriate $\mathrm{P}$ fertilizer management associated with high $\mathrm{P}$ fixation capacity leads to $\mathrm{P}$ 
precipitation that is why $\mathrm{P}$ deficiency is reported in many calcareous soils (Jalali and Ranjbar 2010).

Only $10-20 \%$ of the P applied with fertilizers is taken up by plants in the year of application because the majority of applied $\mathrm{P}$ is rapidly fixed or precipitated into poorly available forms (Alamgir et al., 2012). The $\mathrm{P}$ dissolved from fertilizers undergoes various reactions with the inorganic and organic constituents of the soil resulting in products with varying degrees of solubility. The rates of transformation of fertilizerderived $\mathrm{P}$ into the various soil $\mathrm{P}$ forms provide invaluable information on the plant availability of soil $\mathrm{P}$ at various times after $\mathrm{P}$ application (Rivaie et al., 2008). Soil $\mathrm{P}$ is found in several chemical forms including soluble and exchangeable, organic matter, Ca-bound, Fe-Al- bound and residual phases (Hedley et al., 1982). These phases are remarkably different in bioavailability, mobility and chemical behavior, thus play different roles in soil fertility (Adhami et al., 2013). Information about these fractions may shed some light in our understanding of the P sinks and sources in soil and are essential for an efficient $\mathrm{P}$ management in agricultural fields. Sequential $\mathrm{P}$ fractionation can be used to separate the different forms of soil $\mathrm{P}$ and is useful to compare the fluxes of various P forms in soil (Reddy et al., 2005; Wang et al., 2008).

Humic substances (HS) are macromolecular complex mixtures comprised of aromatic hydroxy carboxylic acid and play a vital role in the mobility and fate of plant nutrients (Yang et al., 2013). It is well known that humic substances improve chemical, biological and physical properties of calcareous soils which, in turn influence the production capacity (Nardi et al., 2002). Humic acids (HAs) and Fulvic acids (FAs) are two major fractions of HS and influence plant growth via improving the physical properties, fertility and moisture condition of the soil (Cahassapis et al.,
2009). The addition of HS to soil can also rectify the problem of P deficiency directly or indirectly through a range of mechanisms including $\mathrm{P}$ release from the residues, competition between $\mathrm{P}$ and HAs and FAs for mineral adsorption sites, exchange of $\mathrm{P}$ sorbed with HS, metal complexation and dissolution reactions ( Fuentes et al., 2006; Alamgir et al., 2012).

Many studies have reported $\mathrm{P}$ sorption inhibition due to site competition and metal complexation by organic acids (Uburger et al., 2011), animal and green manures (Alamgir et al., 2012; Verma et al., 2005) and bioslids (Pinerio et al., 2009), but little is known about the effect of humic substances on soil P lability, transformation rate and forms over time. Thus, the aims of the present research were to investigate the effects of different levels of HAs and FAs on 1) different $\mathrm{P}$ fractions and 2) the pattern and rate of $\mathrm{P}$ release over a period of 45 days.

\section{Materials and Methods}

\subsection{Soil}

Composite soil sample used in this study was collected from 0-30 cm depths of a calcareous soil in Kerman Province, Eastern Iran. Soil sample was air dried, crushed and passed through a $2 \mathrm{~mm}$ sieve for laboratory experiments. Soil $\mathrm{pH}$ and EC were determined in 1:5 ratio of soil: water suspension. Organic C (OC) was measured by the wet oxidation method (Walkley and Black, 1934), calcium carbonate equivalent (CCE) by the method of Allison and Moodie (1965) using acid titration and cation exchange capacity (CEC) using NaOAc method (Rhoads, 1986). Available P were determined by the method described by Olsen et al. (1954) using $0.5 \mathrm{M} \mathrm{NaHCO}_{3}$ at $\mathrm{pH} 8.5$ (1g: $20 \mathrm{ml}$ Soil: extract). 


\subsection{Incubation Study}

For the aerobic incubation, one $\mathrm{kg}$ soil samples were placed in plastic pots and two levels (2 and $4 \%$ ) of Humic acid (HA), Fulvic acid (FA), vermicompost (Verm) and their mixtures including $\mathrm{HA}+\mathrm{FA}$ and $\mathrm{HA}+\mathrm{FA}+$ Verm were thoroughly mixed with soil. Blank (no amendment used) was also among the treatments studied as control. Some chemical properties of used
HS and vermicompost are presented in Table 1. All pots were incubated for 24, 360, 720 and $1080 \mathrm{~h}$ at field capacity. One soil, 11 treatments, four sampling dates and three replications resulted in a total of 132 experimental units in a complete randomized design. After the specified time, samples were taken and analyzed for Olsen-P (Olsen and Sommers, 1982) with P measured by the method of Murphy and Riley (1962). The decrease of Olsen-P with time was fitted by the kinetic equations listed in Table 2 .

Table 1. Selected chemical properties of HA, FA and vermicompost

\begin{tabular}{ccccccc}
\hline $\begin{array}{c}\text { Humic } \\
\text { substances }\end{array}$ & $\begin{array}{c}\mathbf{E C}\left(\mathbf{d S ~ m} \mathbf{~}^{-1}\right) \\
(\mathbf{1 : 1 0 )}\end{array}$ & $\begin{array}{c}\mathbf{p H} \\
\mathbf{( 1 : 1 0 )}\end{array}$ & $\begin{array}{c}\mathbf{P} \\
\left(\mathbf{m g ~ K g}^{-1}\right)\end{array}$ & $\begin{array}{c}\mathbf{Z n} \\
\left(\mathbf{m g ~ K g}^{-1}\right)\end{array}$ & $\begin{array}{c}\mathbf{F e} \\
\left(\mathbf{m g ~ K g}^{-1}\right)\end{array}$ & Purity \\
\hline Humic Acid & 14.3 & 9.4 & 195.5 & 38.4 & 7623.0 & $80 \%$ \\
\hline Fulvic Acid & 29.3 & 5.4 & 244.8 & 309.3 & 933.3 & $70 \%$ \\
\hline Vermicompost & 2.2 & 7.4 & 1760 & 54.0 & 11000.0 & $\begin{array}{c}\text { Humic acid: } 18 \% \\
\text { Fulvic acid: } 15 \%\end{array}$ \\
\hline
\end{tabular}

Table 2. Equations tested to describe P release kinetic data

\begin{tabular}{ccc}
\hline Model & Equation & Parameters \\
\hline Elovich & $\mathrm{q}=\alpha+\beta \ln \mathrm{t}$ & $\alpha$, initial P-desorption rate \\
& & $\beta$, P-desorption constant \\
\hline Parabolic & $\mathrm{q}=\mathrm{A}+\mathrm{Rt}^{1 / 2}$ & $\mathrm{R}$, diffusion rate constant \\
\hline Power & $\ln \mathrm{q}=\ln \mathrm{a}+\mathrm{l} / \mathrm{n} \ln \mathrm{t}$ & $\mathrm{n}$, an empirical constant \\
\hline
\end{tabular}

\subsection{P Fractionation}

The concentration of various $\mathrm{P}$ pools was determined by sequential $\mathrm{P}$ fractionation at 1 and 45 day after incubation, based on Hedley et al. (1982). One g of soil samples were sequentially extracted (at a 1:30 soil: solution ratio) for $16 \mathrm{~h}$ with $\mathrm{H}_{2} \mathrm{O}$ (Soluble P), $0.5 \mathrm{M} \mathrm{NaHCO}_{3}$ (Bioavailable P), 0.1 
$\mathrm{M} \mathrm{NaOH}$ (Fe and Al-bound P) and $1 \mathrm{M} \mathrm{HCl}$ (Ca-bound

$\mathrm{P})$. The amounts of $\mathrm{P}$ in all extracs were determined using colorimetric ascorbic acid method (Murphy and Riley, 1962).

\subsection{Statistical analysis}

The experiment data were subjected to the analysis of variance to test treatment effects on soil Pi fraction and $P$ release. Pearson correlation was used to investigate the relationship between soil Pi fractions with Olsen-P and selected chemical properties of soil.

\section{Results and Discussion}

\subsection{Soil properties}

Selected soil physicochemical properties are listed in Table 3. The textural class of the soil was loamy sand. The soil was neutral to slightly alkaline and low in EC and OC, typical for calcareous soils. The low CEC value obtained for the soil might be related to its low clay and OC contents. The low available P suggests apparent $\mathrm{P}$ deficiency in the soil.

Table 3. Selected physicochemical properties of the used soil

\begin{tabular}{|c|c|c|c|c|c|c|c|}
\hline Texture & Clay & Sand & Silt & $\begin{array}{l}\mathrm{pH} \\
\text { (extract) }\end{array}$ & $\begin{array}{l}\text { EC } \\
\text { (extract) }\end{array}$ & OC $\quad$ CCE & Olsen-P \\
\hline- & & $\mathrm{g} \mathrm{kg}^{-1}$ & & & dS. $m^{-1}$ & $\mathrm{~g} \mathrm{~kg}^{-1}$ & $\mathrm{mg} \mathrm{kg}^{-1}$ \\
\hline loamy sand & 130.2 & 580.3 & 280.6 & 7.7 & 1.7 & $\begin{array}{ll}7.00 & 240.3\end{array}$ & 7.3 \\
\hline
\end{tabular}

\subsection{Released $P$}

Analysis of variance indicated that only main effects of HS addition and time on $\mathrm{P}$ release were significant $(P<0.05)$. Released $\mathrm{P}$ was higher in soils amended with HS and vermicompost than control (Figure 1). The magnitude of the increase in released $\mathrm{P}$ due to vermicompost addition was higher than HS treated soils in all time of incubation. This could be due to higher amount of $\mathrm{P}$ in vermicompost than in HA and FA. The highest released P $(29.4 \mathrm{mg} / \mathrm{kg})$ measured at soil treated with $4 \%$ vermicompost. Soil application of HA and FA at two levels of 2 and $4 \%$ increased released P compared to the control, significantly. However, no difference was found between HS treatments. These results are supported by Selim et al. (2009) on soils of Egypt.

A significant decreasing trend in released $\mathrm{P}$ was found up to 30 day and then leveled off between 30 and 45 days (Figure 2). The decrease in released $\mathrm{P}$ in the soil might be attributed to penetration and adsorption of $\mathrm{P}$ into the porous solids (Jalali and Ranjbar, 2010) and precipitation of Ca-P minerals during incubation. In their study, Short et al (2007) reported that much of the P applied as monocalcium phosphate to Australian soils was converted rapidly to insoluble forms after 4 weeks and only $10 \%$ of added P remained available (90\% fixed) for plant. In the present study, a decrease of $30 \%$ in extractable $P$ from amended soils after 45 days indicates the positive effect of HS and vermicompost on $\mathrm{P}$ availability. 
$\square \mathbf{2} \% \quad \square \mathbf{4} \%$

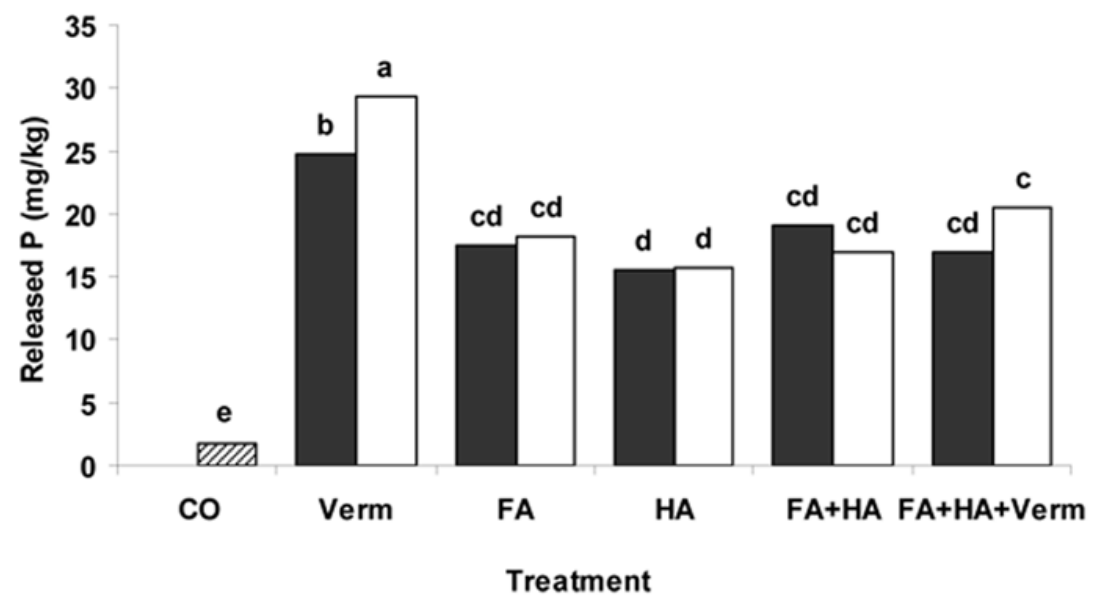

Figure 1. Effect of different humic substances on released $P$. Values are significantly different $(\mathrm{P}<0.05)$ if indicating letter differs

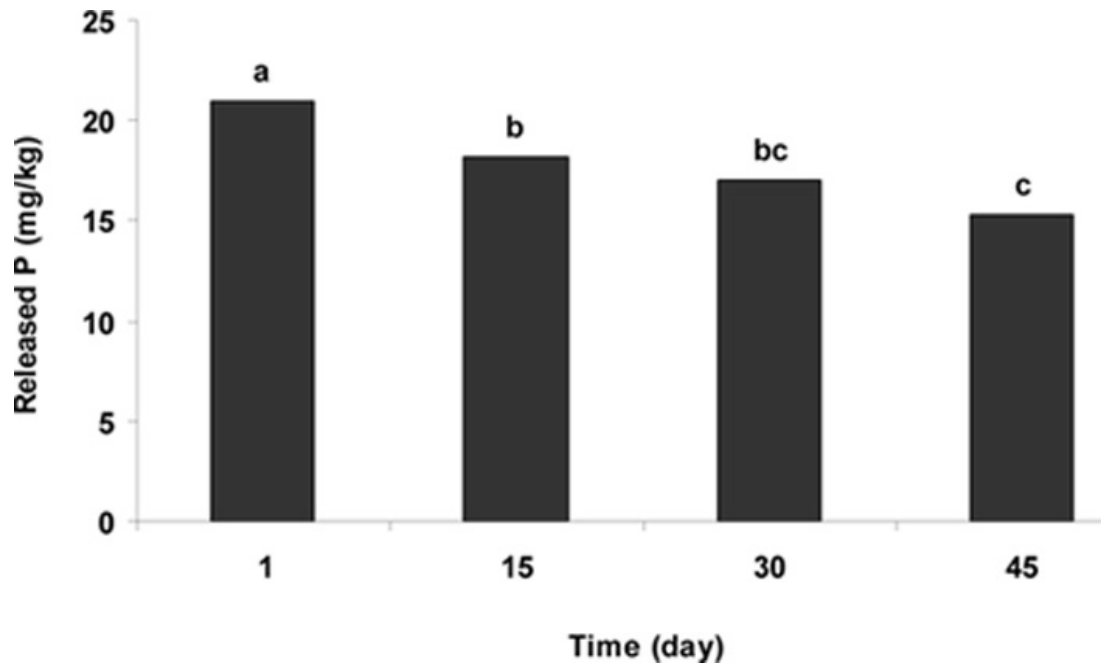

Figure 2. Effect of incubation time on $P$ release. Values are significantly different $(\mathrm{P}<0.05)$ if indicating letter differs

\subsection{Kinetic models}

Different kinetic models were used for explanation of $\mathrm{P}$ release from the amended and non-amended soils. Phosphorus release data were best fitted by the semiempirical and empirical models including parabolic, power and Elovich equations. The coefficients of determination $\left(\mathrm{r}^{2}\right)$ and the standard errors of estimate (S.E.) for kinetic equations tested to describe the P release data (Table 4) and the rate constants derived from these equations are shown in Table 5. Based on the relatively higher values of $r^{2}$ and the lower values of S.E., the parabolic diffusion model was considered the most appropriate equation describing the release of $\mathrm{P}$ with time in amended soil. Fitting of the data to parabolic equation is shown in Figure 3. The linear fit indicates that the release of $\mathrm{P}$ in HS and vermicompost amended soils is a diffusion- 
controlled process. Successful description of P release by the parabolic equation model has been reported in the study of Shariatmadari et al. (2006) and Jalali and Ranjbar (2010) on some calcareous soils of Iran.

\subsection{Phosphorus release rate}

The slope of used equation which represents the loss in P extractability with time can be used as an index of $\mathrm{P}$ transformation. It has a negative value and was used as the $\mathrm{P}$ transformation rate in HS and vermicompost treatments (Table
5). The results showed that $P$ transformation indices increased with application rates in all amended soils. The increase in transformation indices may be due to an increase in the number of adsorption sites. The overall effect of HS and vermicompost on $\mathrm{P}$ transformation rates was in the order of Verm $>\mathrm{HA}>\mathrm{FA}+\mathrm{HA}+$ verm $>\mathrm{FA}+\mathrm{HA}>\mathrm{FA}$. The lowest $\mathrm{P}$ transformation rate found in soils amended with 2 and 4\% FA shows its efficiency to increase $\mathrm{P}$ availability in soil. It seems that FA can decrease the number of adsorption sites and $\mathrm{P}$ affinity more than HA and vermicompost.

Table 4. Coefficients of determination $\left(\mathrm{r}^{2}\right)$ and standard errors of estimate for kinetic equation used to describe $\mathrm{P}$ release in control and amended soils

\begin{tabular}{|c|c|c|c|c|c|c|}
\hline \multirow[t]{2}{*}{ Treatment } & \multicolumn{2}{|c|}{ Parabolic } & \multicolumn{2}{|l|}{ Power } & \multicolumn{2}{|l|}{ Elovich } \\
\hline & $\mathrm{r}^{2}$ & SE & $\mathrm{r}^{2}$ & SE & $r^{2}$ & SE \\
\hline Vermicompost $2 \%$ & $0.85 * *$ & 1.50 & $0.73 * *$ & 0.08 & $0.78^{* *}$ & 1.88 \\
\hline Vermicompost $4 \%$ & $0.93^{* *}$ & 2.91 & $0.81 * *$ & 0.16 & $0.85^{* *}$ & 4.10 \\
\hline Fulvic Acid $2 \%$ & $0.79 * *$ & 0.79 & $0.60 *$ & 0.06 & $0.62 *$ & 1.07 \\
\hline Fulvic Acid 4\% & $0.76^{* *}$ & 0.38 & $0.58^{*}$ & 0.03 & $0.59^{*}$ & 0.50 \\
\hline Humic Acid 2\% & $0.82 * *$ & 1.16 & $0.95 * *$ & 0.04 & $0.95 * *$ & 0.59 \\
\hline Humic Acid 4\% & $0.90^{* *}$ & 1.00 & $0.96 * *$ & 0.03 & $0.97 * *$ & 0.53 \\
\hline (Fulvic Acid+Humic ) $2 \%$ & $0.34^{\mathrm{ns}}$ & 1.50 & $0.18^{\mathrm{ns}}$ & 0.09 & $0.18^{\mathrm{ns}}$ & 1.68 \\
\hline (Fulvic Acid+Humic )4\% & $0.93^{* *}$ & 6.64 & $0.99 * *$ & 0.58 & $0.99 * *$ & 10.44 \\
\hline (Fulvic Acid+Humic+vermicompost )2\% & $0.24^{\mathrm{ns}}$ & 1.58 & $0.13^{\mathrm{ns}}$ & 0.10 & $0.13^{\mathrm{ns}}$ & 1.70 \\
\hline (Fulvic Acid+Humic+vermicompost) $4 \%$ & $0.91 * *$ & 10.5 & $0.72 * *$ & 0.70 & $0.80^{* *}$ & 14.50 \\
\hline Control & $0.83^{* *}$ & 0.51 & $0.65^{*}$ & 0.28 & $0.65^{*}$ & 0.48 \\
\hline Mean & $0.75 * *$ & 2.59 & $0.66^{*}$ & 0.20 & $0.68^{*}$ & 3.41 \\
\hline
\end{tabular}

**: significant at $P<0.001$ and *: significant at $P<0.05$ 
Table 5. Parameters of kinetic equation used to describe P release in control and amended soils

\begin{tabular}{|c|c|c|c|c|c|c|}
\hline \multirow[t]{2}{*}{ Treatments } & \multicolumn{2}{|c|}{ Parabolic } & \multicolumn{2}{|c|}{ Power } & \multicolumn{2}{|c|}{ Elovich } \\
\hline & A & $\mathrm{R}$ & $\ln$ a & $1 / n$ & $\alpha$ & $\beta$ \\
\hline Vermicompost 1 & 29.87 & -0.25 & 3.60 & -0.07 & 34.10 & -1.67 \\
\hline Vermicompost 2 & 43.89 & -0.69 & 4.21 & -0.15 & 55.93 & -4.70 \\
\hline Fulvic Acid $2 \%$ & 19.64 & -0.05 & 3.07 & -0.02 & 21.15 & -0.28 \\
\hline Fulvic Acid 4\% & 19.15 & -0.10 & 2.99 & -0.04 & 19.81 & -0.62 \\
\hline Humic Acid $2 \%$ & 19.11 & -0.17 & 3.17 & -0.077 & 22.81 & -1.30 \\
\hline Humic Acid $4 \%$ & 19.74 & -0.19 & 3.23 & -0.085 & 23.71 & -1.42 \\
\hline (Fulvic Acid+Humic ) $2 \%$ & 20.62 & -0.07 & 3.06 & -0.02 & 21.20 & -0.37 \\
\hline (Fulvic Acid+Humic ) $4 \%$ & 22.61 & -0.27 & 3.44 & -0.11 & 28.16 & -1.99 \\
\hline (Fulvic Acid+Humic+vermicompost ) $2 \%$ & 17.54 & -0.03 & 2.88 & -0.01 & 17.83 & -0.17 \\
\hline (Fulvic Acid+Humic+vermicompost )4\% & 28.06 & -0.36 & 3.65 & -0.11 & 34.01 & -2.38 \\
\hline
\end{tabular}

\subsection{Inorganic P fractions}

Since maximum P release was found at vermicompost amended soil, fractionation of Pi was only performed in 2 and $4 \%$ vermicompost treatments. Concentrations of inorganic $\mathrm{P}$ fractions are presented in Table 6 . In all treatments, $\mathrm{H}_{2} \mathrm{O}-\mathrm{Pi}$ constituted the smallest $\mathrm{P}$ fraction (2-7 \% of total Pi) whereas HCl-Pi (42-89\% of total Pi) was the most abundant fraction (Figure 4). This was likely due to calcareous nature of studied soil. Similar results were reported by Pinerio et al., (2009) and Dail et al., (2009) in organic amended soils.

Table 6. Inorganic $P$ fractions in amended and control soils at 1 day and 45 days after incubation

\begin{tabular}{|c|c|c|c|c|c|c|c|c|}
\hline \multirow{2}{*}{ Treatments } & \multicolumn{2}{|c|}{$\mathrm{H}_{2} \mathrm{O}-\mathrm{P}$} & \multicolumn{2}{|c|}{$\mathrm{NaHCO}_{3}-\mathrm{P}$} & \multicolumn{2}{|c|}{$\mathrm{NaOH}-\mathrm{P}$} & \multicolumn{2}{|c|}{ HCl-P } \\
\hline & $24 \mathrm{~h}$ & $1080 \mathrm{~h}$ & $24 \mathrm{~h}$ & $1080 \mathrm{~h}$ & $24 \mathrm{~h}$ & $1080 \mathrm{~h}$ & $24 \mathrm{~h}$ & $1080 \mathrm{~h}$ \\
\hline Control & $17.8 \mathrm{~b}$ & $12.7 \mathrm{~b}$ & $29.0 \mathrm{c}$ & $24.4 \mathrm{c}$ & $27.6 \mathrm{~b}$ & $27.9 \mathrm{~b}$ & $338.5 \mathrm{bc}$ & $538.9 \mathrm{a}$ \\
\hline Verm $2 \%$ & $36.4 \mathrm{ab}$ & $19.8 \mathrm{~b}$ & $189.4 \mathrm{a}$ & $101.1 \mathrm{~b}$ & $74.2 \mathrm{ab}$ & $70.7 \mathrm{ab}$ & $459.3 \mathrm{ab}$ & $441.1 \mathrm{ab}$ \\
\hline Verm 4\% & $37.6 \mathrm{a}$ & $36.6 \mathrm{ab}$ & $218.1 \mathrm{a}$ & $179.0 \mathrm{a}$ & $96.5 \mathrm{a}$ & $72.5 \mathrm{ab}$ & $226.6 \mathrm{c}$ & $213.1 \mathrm{c}$ \\
\hline
\end{tabular}

For each fraction, same letters are not significantly different at 0.05 probability level 

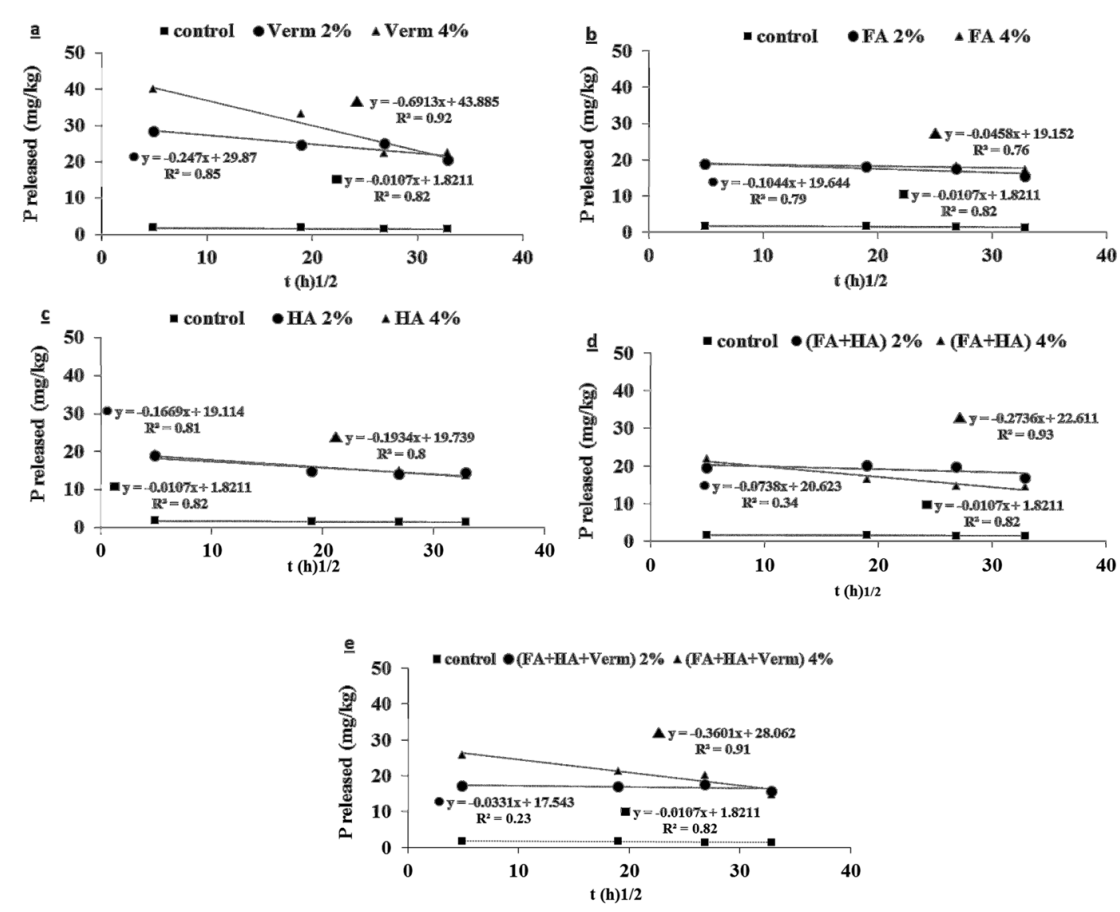

Figure 3. Relationships between observed and predicted $\mathrm{P}$ released in HS and vermicompost amended soils as described by parabolic model (a: vermicompost, b: Fulvic acid, c:Humic acid, d: Fulvic acid+Humic acid and e: Humic acid+Fulvic acid+Vermicompost)

The $\mathrm{H}_{2} \mathrm{O}$ and $\mathrm{NaHCO}_{3}$-Pi are considered as labile fractions (Guo et al., 2000). Application of vermicompost at the level of $4 \%$ increased both $\mathrm{H}_{2} \mathrm{O}-\mathrm{Pi}$ and $\mathrm{NaHCO}_{3}-\mathrm{Pi}$ compared to control. Verma et al. (2005) also reported an increase in $\mathrm{NaHCO}_{3}$-Pi due to manure application. Although a slight reduction in these fractions was found in amended soils after 45 days, the remained $\mathrm{H}_{2} \mathrm{O}$ and $\mathrm{NaHCO}_{3}$-Pi seems to provide sufficient $\mathrm{P}$ for plant growth. Although, $\mathrm{NaHCO}_{3}-\mathrm{Pi}$ distribution was approximately unchanged in control after $45 \mathrm{~d}$ of incubation, it was decreased by 25 and $37 \%$ in soil amended with 2 and $4 \%$ vermicompost, respectively (Figure 4).

The Pi extracted by $\mathrm{NaOH}$ is considered as $\mathrm{Pi}$ associated with $\mathrm{Fe}$ and $\mathrm{Al}$ components (Hedley et al., 1982) and is often assumed to be a moderately labile fraction (Guo et al., 2000). The NaOH-Pi has been reported to be an important $\mathrm{P}$ sink for the crops in low P-input systems (Verma et al., 2005). NaOH-Pi content of soil was higher at $4 \%$ vermicompost treatment than control and remained unchanged over time (Table 6). This observation suggested that the $\mathrm{NaOH}-\mathrm{Pi}$ may maintain adequate plant available-P in studied soil. Supporting this idea is the positive correlation $\left(\mathrm{r}=0.80^{* *}\right)$ found between $\mathrm{NaOH}-\mathrm{Pi}$ and Olsen P. The results are similar to those reported by Dail et al. (2009) in the poultry manure amended soil.

The HCl-Pi fraction, which represents Ca-P minerals, is low in availability for plants (Hedley et al., 1982). At the end of the experiment, a significant decrease 
was found in soil HCl-Pi fraction after vermicompost application at the level of 4\%. HCl-Pi distribution decreased from $89 \%$ in control to $69 \%$ and $42 \%$ in 2 and $4 \%$ vermicompost treatments (Figure 4). Calcium phosphates are thermodynamically the most stable $\mathrm{P}$ minerals, although they were found to decrease in greenhouse studies (Guo et al., 2000; Uygur and
Karabatak, 2009).The result is similar to the study of Abolfazli et al. (2012) who reported that Ca-P mineral reduced following application of cow dung manure. in amended and non-amended soil, calcium phosphate minerals comprised the largest fraction of soil $\mathrm{Pi}$ indicating that the added $\mathrm{P}$ was transformed into the stable Ca-P minerals at the end of the experiment.

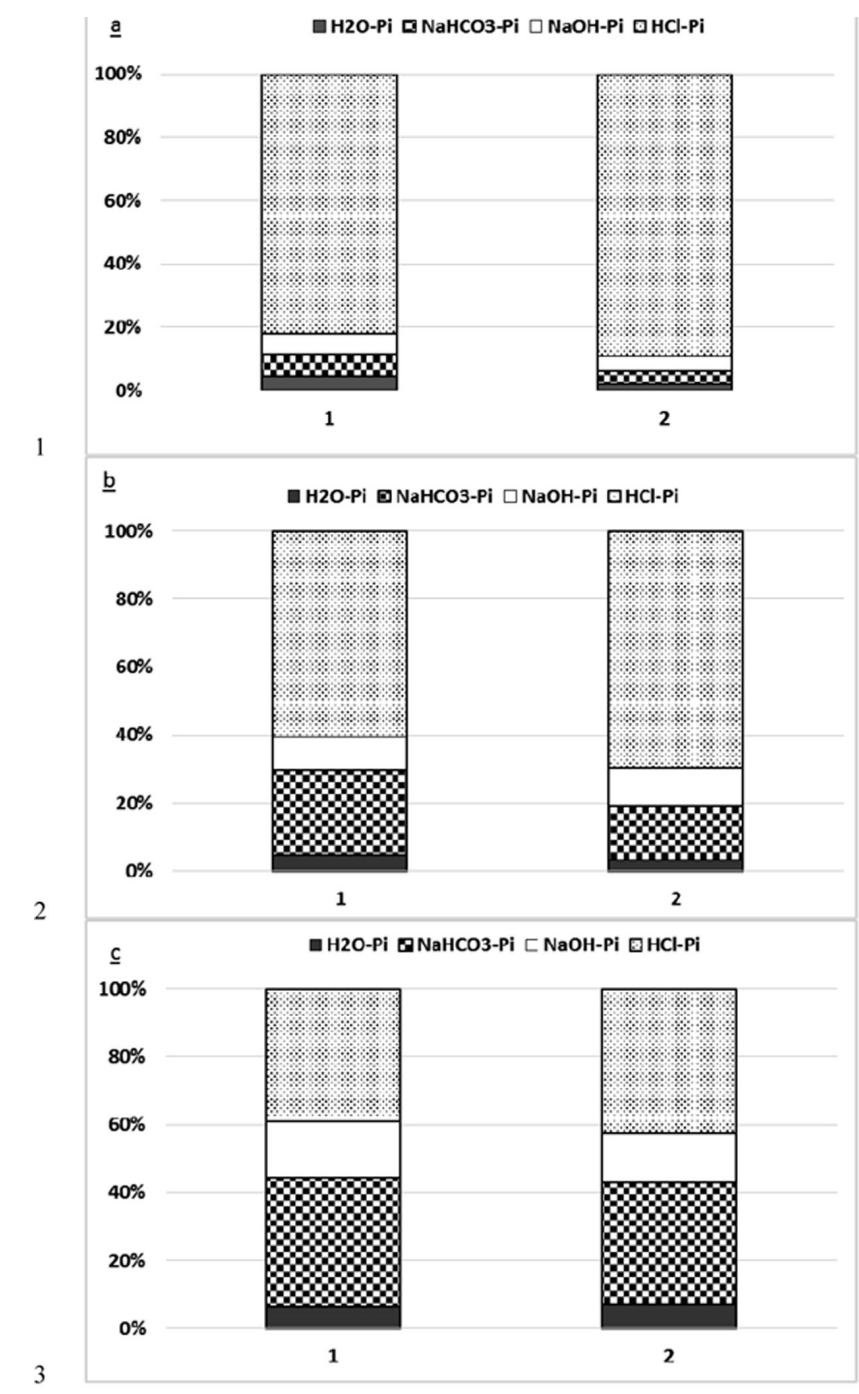

Figure 4. Soil Pi distribution at the beginning (1) and end (2) of experiment at control (a), 2\% vermicompost (b) and 4\% vermicompost (c) treatments. 
3.6. Correlation between Pi fractions with Olsen-P and soil properties

Simple correlation analysis between four Pi fractions with Olsen-P and some soil chemical properties is shown in Table 7. The highest correlation coefficients were found among Olsen-P and $\mathrm{NaHCO}_{3}$ and $\mathrm{NaOH}$ $\mathrm{Pi}$ fractions, whereas no significant correlation was found between Olsen-P and HCl-Pi. These results confirmed that $\mathrm{NaOH}-\mathrm{Pi}$ and $\mathrm{NaHCO}_{3}-\mathrm{Pi}$ in soil play as a sink of available P. Soil OC was positively correlated with $\mathrm{H}_{2} \mathrm{O}-\mathrm{Pi}, \mathrm{NaHCO}_{3}-\mathrm{Pi}$ and $\mathrm{NaOH}-\mathrm{Pi}$ among soil chemical properties, whereas correlation was negative with $\mathrm{HCl}-\mathrm{Pi}$. Carbonate calcium is a very strong complexing agent for $\mathrm{P}$ in soils. Based on results of the present research, organic matter can increase availability of soil $\mathrm{P}$ through dissolution of stable $\mathrm{HCl}$ Pi to more labile forms such as $\mathrm{H}_{2} \mathrm{O}$ and $\mathrm{NaHCO}_{3}$-Pi. These results are supported by other published reports (Hao et al., 2008; Nafilu, 2009; Dail et al., 2009).

Table 7. Pearson correlation coefficient $\left(\mathrm{r}^{2}\right)$ for soil properties and Pi fractions

\begin{tabular}{cccccccccc}
\hline & $\mathrm{H}_{2} \mathrm{O}-\mathrm{P}$ & $\mathrm{NaHCO}_{3}-\mathrm{P}$ & $\mathrm{NaOH}-\mathrm{P}$ & $\mathrm{HCl}-\mathrm{P}$ & Olsen-P & $\mathrm{pH}$ & $\mathrm{EC}$ & $\mathrm{CCE}$ & $\mathrm{OC}$ \\
\hline $\mathrm{H}_{2} \mathrm{O}-\mathrm{P}$ & - & $0.64^{* *}$ & $0.63^{* *}$ & -0.32 & $0.61 * *$ & 0.02 & 0.15 & -0.28 & $0.52^{*}$ \\
$\mathrm{NaHCO}_{3}-\mathrm{P}$ & & - & $0.67 * *$ & -0.25 & $0.90 * *$ & 0.07 & 0.40 & -0.33 & $0.76^{* *}$ \\
$\mathrm{NaOH}-\mathrm{P}$ & & & - & -0.28 & $0.80^{* *}$ & -0.37 & -0.37 & -0.08 & $0.61^{* *}$ \\
$\mathrm{HCl}-\mathrm{P}$ & & & & - & -0.29 & 0.13 & -0.39 & 0.11 & $-0.57 * *$ \\
Olsen-P & & & & - & -0.22 & 0.37 & -017 & $0.75^{* *}$ \\
$\mathrm{pH}$ & & & & & - & 0.08 & $-0.51^{*}$ & -0.15 \\
$\mathrm{EC}$ & & & & & & - & -0.06 & 0.22 \\
$\mathrm{CCE}$ & & & & & & & & - & -0.36 \\
$\mathrm{OC}$ & & & & & & & & & - \\
\hline
\end{tabular}

*, ** significant at $P<0.05$ and $P<0.01$, respectively.

\section{Conclusions}

This study clearly showed that soil application of HA, FA, vermicompost and their mixtures had different effects on $\mathrm{P}$ availability. In all treatments the timedependent $\mathrm{P}$ release processes were best fitted by the parabolic diffusion equation. In spite of higher released $\mathrm{P}$ in soil treated with vermicompost, lower transformation rate indices were found in HA and FA amended soils indicating more effectiveness of HS on $\mathrm{P}$ availability. In vermicompost amended and nonamended soil, P was associated mainly with HCl-Pi
(42-89\%), $\mathrm{NaHCO}_{3}-\mathrm{Pi}$ (4-37\%), NaOH-Pi (4-17\%), and $\mathrm{H}_{2} \mathrm{O}-\mathrm{Pi}(2-7 \%)$. Increased distribution of $\mathrm{NaOH}-$ $\mathrm{Pi}$ and $\mathrm{HCl}-\mathrm{Pi}$ with time indicates the transformation of labile fractions $\left(\mathrm{H}_{2} \mathrm{O}-\mathrm{Pi}\right.$ and $\left.\mathrm{NaHCO}_{3}-\mathrm{Pi}\right)$ to these stable fractions. The multivariate analyses confirmed that $\mathrm{NaHCO}_{3}$-Pi was the most important fraction contributing to plant available $\mathrm{P}$.

\section{Acknowledgments}

We would like to thank Dr Mohammad Hadi Farpour for assistance with manuscript development. 


\section{References}

Abolfazli, F., Forghani, A., Norouzi, M. 2012. Effects of phosphorus and organic fertilizers on phosphorus fractions in submerged soil. J. Soil Sci. Plant Nutr. 12, 349-362.

Adhami, E., Owliaie, H. R., Molavi, R., Rezaei Rashti, M., Esfandbod, M. 2013. Effects of soil properties on phosphorus fractions in subtropical soils of Iran. J. Soil Sci. Plant Nutr. 13, 11-21.

Alamgir, M., McNeill, A., Tang, C., Marschner, P. 2012. Changes in soil $\mathrm{P}$ pools during legume residue decomposition. Soil Biology \& Biochemistry. 49, 70-77.

Allison, L.E., Moodie, C.D. 1965. Carbonates. In: A. Black (Ed.), Methods of Soil Analysis: Part 2. Am. Soc. Agron, Madison, pp:1379-1396.

Bai, Z., Li, H., Yang, X., Zhou, B., Shi, X., Wang, B., Li, D., Shen, J., Chen, Qin, W., Oenema, O., Zhang, F. 2013. The critical soil P levels for crop yield, soil fertility and environmental safety in different soil types. Plant Soil. 372, 27-37.

Cahassapis, K., Roulia, M., Tsirigoti, D. 2009. Chemistry of metal-humic complexes contained in Megalopolis lignite and potential application in modern organomineral fertilization. International Journal of Coal Geology. 78, 288-295.

Dail, H.W., He, Z., Erich, S.M., Honeycutt, W.C. 2009. Soil phosphorus dynamics in response to poultry manure amendment. Soil Sci. 174, 195201.

Fuentes, B., Bolan, N., Naidu, R., Luz Mora, M. 2006. Phosphorus in Organic waste-soil system. J. Soil Sc. Plant. Nutr. 6, $64-83$.

Guo, F., Yost, R.S., Hue, N.V., Evensen, C.I., Silva, J.A. 2000. Changes in phosphorus fractions in soils under intensive plant growth. Soil Sci. Soc. Am. J. 64, 1681-1689.
Hao, X., Godlinski, F., Chang, C. 2008. Distribution of phosphorus forms in soil following long-term continuous and discontinuous cattle manure applications. Soil Sci. Soc. Am. J. 72, 90-97.

Hedley, M.J., Stewart, J.W.B., Chauhan, B.S. 1982. Changes in inorganic and organic soil phosphorus fractions induced by cultivation practices and by laboratory incubations. Soil Sci. Soc. Am. J. 46, 970.

Jalai,M., Ranjbar, F. 2010. Aging effects on phosphorus transformation rate and fractionation in some calcareous soils. Geoderma. 155,101106.

Leytem, A.B., Mikkelson, R.L. 2005. The nature of phosphorus in calcareous soils. Better Crop. 89, 11-13.

Murphy, J., Riley, J.P. 1962. A modified single solution method for determination of phosphate in natural waters. Anal. Chim. Acta. 27, 31-36.

Nafilu, A. 2009. Effects of soil properties on the kinetics of desorption of phosphate from alfisol by anion-exchange resins. J. Plant Nutr. Soil Sci. 172, 101-107.

Nardi, S., Pizzeghello, D., Muscolo, A., Vianello, A. 2002. Physiological effects of humic substances on higher plants. Soil Biology \& Biochemistry. 34, 1527-1536.

Olsen, S. L., Sommers, L. E. 1982. Phosphorus In: A.C. Page (ed). Methods of soil analysis, part 2, 2nd ed..Agron. Monogr. No. 9, ASA and SSSA, Madison WI. pp: 403-427.

Olsen, S.R., Cole, C.V., Watanabe, E.S., Dean, L.A. 1954. Estimation of available phosphorus in soils by extraction with sodium bicarbonate. U.S. Dep. Agric. Cir, 939 p.

Pinerio, A.L., Cabera, D., Pena, D. 2009. Phosphorus Adsorption and fractionation in a two-phase olive mill waste amended soil. Soil Sci. Soc. Am. J. 73, 1539-1544. 
Reddy, D.D., Rao, S.A., Singh, M. 2005. Changes in P fractions and sorption in an alfisol following crop residues application. J. Plant Nutr. Soil Sci. 168, 241-247.

Rhoads, J.W. 1986. Cation exchange capacity. In: A.C. Page (ed). Methods of Soil Analysis. Part 2. Am. Soc. Agron, Madison, pp: 149-158.

Rivaie, A.A., Loganathan, P., Graham, J.D., Tillman, R.W., Payn, T.W. 2008. Effect of phosphate rock and triple superphosphate on soil phosphorus fractions and their plant-availability and downward movement in two volcanic ash soils under Pinus radiate plantations in New Zealand. Nutr. Cycl. Agroecosyst. 82, 75-88.

Selim, E.M., Mosa, A.A., El-Ghamry, A.M. 2009. Evaluation of humic substances fertigation through surface and subsurface drip irrigation systems on potato grown under Egyptian sandy soil conditions. Agricultural Water Management. 96, 1218-1222.

Shariatmadari, H., Shirvani, M., Jafari, A. 2006. Phosphorus release kinetics and availability in calcareous soils of selected arid and semiarid toposequences. Geoderma. 132, 261-272.

Short, T.A., Kopittke, P.M., Mulligan, D.R., Menzies, N.W. 2007. Growth of Eucalyptus species in a Brown Kandosol, and changes in soil phosphorus fractionation following fertilisation. Aust. J. Soil Res. 45, 190-198.
Uburger, E., Jones, D.L., Wenzel, W.W. 2011. Phosphorus saturation and $\mathrm{pH}$ differentially regulate the efficiency of organic acid anionmediated P solubilization mechanisms in soil. Plant Soil. 341, 363-382.

Uygur, V., Karabatak, I. 2009. The effects of organic amendments on mineral phosphate fractions in calcareous soils. J. Plant Nutr. Soil Sci. 172, 336345 .

Verma, S., Subehia, S.K., Sharma, S.P. 2005. Phosphorus fractions in acid soil continuously fertilized with mineral and organic fertilizers. Biol. Fertil. Soils, 41, 295-300.

Wang, B., Shen, J., Tang, C., Rengel, Z. 2008. Root morphology, proton release, and carboxylate exudation in lupin in response to phosphorus deficiency. J. Plant Nutr. 31, 557-570.

Walkley, A., Black, I.A. 1934. An examination of Degtjareff method for determining soil organic matter and a proposed modification of the chromic acid in soil analysis. 1. Experimental. Soil Sci. 79, 459-465.

Yang, S., Zhang, Z., Cong, L., Wang, X., Shi, S. 2013. Effect of fulvic acid on the phosphorus availability in acid soil. J. Soil Sci. Plant Nutr. 13, 526-533. 